When ready to pupate the larva spins up a cluster of leaves, or a roll, if on banana, and spins a loose, tough web of brown silk, within which it undergoes its last molt. Males averaged 18.5 days for the pupa stage with a variation of 17-20 days; females averaged 16.5 days with a variation of $15-18$ days.

\title{
ENEMIES
}

The Ichneumon Eremotylus angulatus Hooker is a parasite of the larva. Dead larvæ are often found with a strong growth of what is apparently a species of Empusa.

\section{ELUCIDATIONS OF NEW ENGLAND MUSCOIDEA}

\author{
BY CHARLES H. T. TOWNSEND
}

Certain forms that have been confused specifically, or wrongly referred generically, are elucidated in this paper. Various other forms, believed to be undescribed, are added. External adult-character descriptions are included of several forms that have thus far stood on reproductive and early-stage characters only.

\section{Family CALIRRHOID王}

Ochrocera, new genus.

Genotype, Ochrocera vaginalis Townsend, new species.

Allied to Arctophyto, from which it differs as follows: Female. All the macrochætæ strong, body not hairy; no facial carina, the antennæ not widely separated; frontal bristles closely placed, about 10 on each side; front more produced, the parafacials broader; cheeks about three-fifths of eyeheight ; three proclinate fronto-orbitals ; two or three extra pairs of ocellars, shorter than front pair; palpi well dilated at tip; cubitus rectangular, with a strong stump; abdomen scarcely widened, with strong erect discals and marginals, including median marginal pair on first segment, otherwise with only short appressed microchætæ and no hairs. Bears a strong resemblance to Paramacronyhia, from which it may be distinquished by the bare parafacials and the discal abdominal macrochætæ. 
Ochrocera vaginalis, new species.

Length of body, 11 to $11.5 \mathrm{~mm}$; of wing, $9.5 \mathrm{~mm}$. Two females, Base Station, Mount Washington, New Hampshire, August 27 and 31,1914 , on flowers of Solidago canadensis (Townsend).

Black, rather shining. Third antennal joint and tips of palpi ocherous or clear light orange; the first two antennal joints, arista, and rest of palpi rufotestaceous. Frontalia black, cheek grooves brown; rest of head silvery-white, shading to blackish with incidence of light, leaving a rectangular dark patch on parafacials in direct view and the posterior half of parafrontals dark except the inner edge. Thorax and scutellum silvery, with three heavy equal uninterrupted black vittæ. Abdomen silvery submarmorate, shining, the only tangible marking being a more or less defined median vitta. Llegs black. Wings clear. Tegulæ white.

Holotype, No. 19595, U. S. Nat. Mus. Paratype, TD4332.

\section{Family SARCOPHAGID㤅}

Protodexia Townsend.

Ann. Ent. Soc. Amer. IV, 139, 151 (June, 1911)-As TD354, without name.

Journ. N. Y. Ent. Soc. XX, 117-118 (June, 1912).

Genotype, Protodexia synthetica Townsend, 1912, 1. c.

Differs from Ravinia as follows: Female. Front equilateral, hardly over two-sevenths of head-width; frontalia a little narrower than one parafrontal, very slightly narrowing posteriorly to divergence at ocellar area; two proclinate fronto-orbitals, one reclinate behind and in line with them; anterior pair of frontals slightly diverging from line of others. Parafacials very narrow, distinctly narrower than length of second antennal joint, with irregular row of fine hairs. Cheek grooves subtriangular, well impressed, the upper and outer angles sharply pointed and elongate; cheeks much narrower, distinctly less than half eye-height. Face widens abruptly and rapidly from front, distance between lower ends of eyes being more than twice frontal width. Facial depression very rounded, widened 
below, but little higher than broad, the outer bowed edge of facialia with minute bristles half way up; vibrissæ inserted distinctly above the oral margin, the epistoma appreciably constricted by the vibrissal angles. Third antennal joint about twice the length of the rather elongate second. Only three postsuturals, only two preacrostichals and one postacrostichal; three sternopleurals; second abdominal segment with closelyset marginal row of short appressed bristles, third segment with marginal row of erect short ones, anal segment with only row of erect short microchætæ representing the usual marginal bristles. Front tarsi slender; the front claws much shorter, weaker and more curved than the others. Third vein with four or five bristles at base reaching nearly halfway to small cross-vein, strongly bowed upward on distal half.

Protodexia synthetica Townsend.

Length of body, $6 \mathrm{~mm}$.; of wing, $4.75 \mathrm{~mm}$. One female, Melrose Highlands, Massachusetts, August 14, 1908 (D. H. Clemons).

Blackish, pale golden pollinose all over, the parafrontals and parafacials more deeply golden, the occiput ashy. Three fairly distinct vittæ extending over thorax and abdomen. Legs thickly pollinose, except tarsi which are deep black. Wings clear. Tegulæ whitish, with yellowish margins. Palpi and most of antennæ light rufous. Frontalia brown.

Holotype, No. 19476, U. S. Nat. Mus. TD354.

Eubrachycoma, new genus.

Genotype, Brachycoma apicalis Coquillett, 1897, Rev. Tach. 131.

Differs from Brachicoma as follows: Male. Parafacials finely hairy, the hairs not disposed in rows. Palpi not appreciably enlarged apically. Cheeks about one-half of eye-height. About 16 bristles on hind margin of third abdominal segment. Scutellar bristles not so strong; abdomen rather more hairy. Claws very strongly elongate. Hind crossvein not quite parallel with apical crossvein, not at all in line with same. Vibrissæ on or close to oral margin.

The holotype is a male from Connecticut. 


\section{Family SALMACIID压}

Euceromasia Townsend.

Ann. Ent. Soc. Amer. IV, 146 (June, 1911)-As TD390, without name.

Journ. N. Y. Ent. Soc. XX, 112-113 (June, 1912.)

Genotype, Euceromasia spinosa Townsend, 1912, 1. c.

Runs to Masicera myoidaa in Coquillett's Rev. Tach. Differs from Paraphorocera radicis T. (subgenus B) as follows: Female. Front at vertex less than one-fourth of head-width, face below about one-half same. Outer vertical vestigial, not at all developed. Antennæ slightly more slender, relative length of joints same; second aristal joint not elongate. Cheeks a little narrower, parafacials narrower and more rapidly narrowed below; eyes with faint hairs that are a little more easily distinguished. Front not so produced in profile; frontalia averaging as wide as one parafrontal. Practically the identical chætotaxy of thorax, scutellum, and abdomen; second segment without discals, the discals of third segment rather weak, anal segment with a scattering of short erect microchætæ. Abdomen deep, tip rather rounded. Apical cell ends a little nearer wing-tip, and the cubitus is well approximated to margin. Two to three bristles on base of third vein.

Euceromasia spinosa Townsend.

Length of body, $7.5 \mathrm{~mm}$.; of wing, $6.25 \mathrm{~mm}$. One female, North Andover, Massachusetts, August 20, 1908 (Clemons).

Differs in coloration from Paraphorocera radicis as follows: Palpi are obscure rufous, with black on tips and sides. Frontalia are rich brown. All other coloration, including the distribution of pollen, agrees perfectly except only that the tegulæ are more nearly white.

Holotype, No. 19471, U. S. Nat. Mus. TD390.

\section{Family CROCUTIDÆ}

Anthomyiopsis, new genus.

Genotype, Anthomyiopsis cypseloides Townsend, new species. Female. Tegulæ small, the hind scale not twice as large as 
the front one. Apical crossvein pushed close to margin of wing. Macrochætæ bristlelike. Front at vertex about equal to one eye, slightly widening anteriorly, the face widening therefrom at about same angle. Two proclinate orbitals, one reclinate one; both verticals developed, proclinate ocellars present. Parafrontals each a little over half as wide as frontalia. Frontals stopping close to base of antennæ. Parafacials narrowed below. Cheeks about one-fourth or one-fifth of eyeheight. Epistoma cut off, vibrissæ nearly level with oral margin. Facialia bare. Second antennal joint short, third hardly over twice length of second. Arista pubescent, thickened on basal third, basal joints short. Proboscis short and fleshy, palpi well thickened apically. Abdomen broad, shortovate; second segment with weak marginal macrochætæ and a median discal, third and fourth segments covered with same moderately thickly and evenly disposed. Legs normal. Wings elongate, rather narrow. Costal spine very small, the costa well bulged basad of same. Apical cell very narrowly open, ending in exact wing-tip. Hind crossvein straight, at right angle to fourth vein, slightly nearer to small crossvein than to cubitus, latter rounded and much approximated to wingmargin; apical crossvein subparallel with margin.

Anthomyiopsis cypseloides, new species.

Length of body, $3.5 \mathrm{~mm}$. (abdomen flexed); of wing, $4 \mathrm{~mm}$. One female, Franconia, New Hampshire (Mrs. A. T. Slosson).

Shining black. Face silvery; frontalia dark brown, with slight bloom; parafrontals thinly silvery. Antennæ and palpi light rufous. Thorax and scutellum very thinly dusted with silvery, thoracic vittæ obsolete. Abdomen without bloom. Legs black. Wings nearly clear, veins yellowish. Tegulæ yellowish-tawny, the front scale more whitish.

Holotype, No. 19569, U. S. Nat. Mus.

Psalidopteryx, new genus.

Genotype, Psalidopteryx slossonce Townsend, new species.

Female. Head in profile subhemispherical, lower and frontal 
profiles curved. Front view shows head to be much broader than high. Front almost equilateral, wider at vertex than one eye. Antennal and vibrissal axes about equal. Facial plate short, broad below, subtriangular, epistoma cut off, the vibrissæ about level with oral margin. Facialia bare. Proboscis short, fleshy; palpi subfiliform, slightly thickened at tip. Antennæ inserted well above eye-middle, second joint short, third joint only slightly longer than second. Arista thickened on basal third, basal joints very short. Eyes bare, descending a little short of the vibrissal level. Frontals few, descending but little below base of antennæ; both verticals developed; two proclinate fronto-orbitals, and one reclinate; proclinate pair of ocellars. Frontalia narrowing posteriorly, at widest much narrower than parafrontals. Parafacials much narrowed below, bare. Cheeks about two-fifths eye-height. Sternopleurals, $1: 0: 1$, some very weak hairlike bristles between them; postsuturals, 3 ; preacrostichals, 3 weak; postacrostichals, 4 , but all except the hind one are weak. Three lateral scutellars, an equally long decussate apical pair, and a weak approximated discal pair. Abdomen almost perfectly ovate in outline from above, very bristly ; first segment with only a very weak median marginal pair of bristles and some stronger mraginal ones laterally; second with a long median discal, some lateral discals, and a marginal row of which the median pair is strongest; third and fourth segments with complete discal and marginal rows, the fourth segment being very convex and with extra bristles between the discal and marginal rows. All the macrochætæ are erect or suberect. Costal spine small. Venation like Psalida, petiole of apical cell about as long as hind crossvein, latter about in middle between cubitus and small crossvein, cubitus almost but not quite evenly rounded. No veins bristled, except third at base. Tegulæ normal. Claws short.

Psalidopteryx slossonæ, new species.

Length of body, $3.75 \mathrm{~mm}$.; of wing, nearly $3.5 \mathrm{~mm}$. One female, Mount Washington, New Hampshire (Mrs. A. T. Slosson). 
Blackish, cinereous pollinose. Antennæ, frontalia, palpi, and legs black. First two abdominal segments subshining brownish-black; the second rather broadly pollinose on base except on median line, the pollen area of each side distended posteriorly next median line. All other parts thickly pollinose, the bristle origins of last two abdominal segments marked with black dots. Wings clear. Tegulæ watery-whitsh. Thoracic vittæ practically obsolete.

Holotype, No. 19566, U. S. Nat. Mus.

Named in honor of Mrs. A. T. Slosson.

\section{Family DEXIID王}

Spathidexia Townsend.

Genotype, Spathidexia clemonsi Townsend, 1912, Journ. N. Y. Ent. Soc., XX, 110.

Differs from Thelairodes as follows: Both sexes with two proclinate fronto-orbitals. Hind claws of male about as long as others, all thickly pubescent. Costal spine vestigial, or slightly developed. Arista short-hairy above and below. Femora not modified, tibiæ not hairy. Male front at vertex about two-thirds of eye. Palpi of male short, small, little swollen apically. Third antennal joint of male bulged on upper border.

Female claws short. Female front and face about same width, as wide as one eye or slightly wider. Palpi of female elongate, much enlarged apically. Long heavily-chitinized blade-like larvipositor present, projecting posteriorly and not lownward. This larvipositor can not be used for piercing skin of host, since there are no heavy muscles in connection with it.

\section{Spathidexia clemonsi Townsend.}

Length of body, 6.5 to $7.5 \mathrm{~mm}$.; of female wing, $5.5 \mathrm{~mm}$.; of male wing, $6 \mathrm{~mm}$. Three females, Lexington, Kentucky; Melrose Highlands, Massachusetts (Clemons); Rock Creek Park, District of Columbia, May 23, 1915 (Townsend); one male, Riverton, New Jersey, May 30 (C. W. Johnson). 
Black, with silvery-white pollen. Inner edge of parafrontals, vertex, ocellar area, mesoscutum, and scutellum light golden. Pleuræ, coxæ, outside of front femora, rest of head, and broad bases of abdominal segments 2 to 4 silvery-white. Palpi and labella pale yellow. End of second antennal joint and base of third pale rufous. Unpollinose parts of abdomen polished black. Legs black. Wings clear. Squamæ and squamulæ watery-white. The silvery-white pollen is seen in oblique view to cover the blackish frontalia.

Male with abdomen broadly yellow on base, showing in tergal lunule on each side extending back to front corner of third segment, and including whole venter to middle of same segment. Front tibiæ of male are testaceous, those of female hardly less so.

Holotype, No. 1946\%, U. S. Nat. Mus., female, TD371. Allotype, male. Paratypes include TD4453, female.

\section{Family LARV无VORID王}

Larvævoropsis new genus.

Genotype, Echinomyia dakotensis Townsend, 1892, Trans. Am. Ent. Soc. XIX, 94.

Differs from Larvavora as follows: Whole body much narrower, the abdomen not especially broadened, form Peleterialike. Second antennal joint of female hardly more than one and one-fourth times the third, that of male shorter. Front of male at vertex about two-thirds eye-width, that of female about equal to eye-width. Third antennal joint of male not strongly broadened apically. Cheeks of male about one-half of eye-height, those of female a little broader. Parafacials with sparse bristly hairs, not pilose. Strong apical decussate pair of scutellar macrochætæ; four laterals, the alternating ones weak, especially so in female; two discal pairs, the anterior pair widely separated and forming with the other pair an arcuate row. No median marginal bristles on first abdominal segment, only a median marginal pair on second, a loose marginal row on third, loose marginal and discal on fourth segment. Abdominal macrochætæ not nail-like or truly spine- 
like. Anal segment not noticeably emarginate. Cubitus farther removed from hind margin of wing, almost as near front margin.

Larvævoropsis orientalis Townsend, new name.

Larvavoropsis orientalis Townsend new name for Echinomyia florum Coquillett, 189\%, Rev. Tach. 144, Franconia, New Hampshire (nec Tachina florum Walker, 1849, List IV, 722). Holotype male, allotype female, on same pin. Type, No. 19596, U. S. Nat. Mus.

Differs from dakotensis by the face and cheeks being golden pollinose. The female has the abdomen wholly black except anal segment.

May be known from Fabriciodes montana by the anal segment of male being rufous or yellowish-rufous with only a little black on median line basally. Macrochætæ strong, body not long-hairy. Scutellum dark testaceous apically, the base broadly black. First aristal joint short in both sexes. TD4365, 4378 , both male.

A common species in New England.

Echinomyodes, new genus.

Genotype, Echinomyodes piceifrons Townsend, new species, for Echinomyia algens Coquillett, 1897, Rev. Tach. 144, pt., holotype labeled "Vermont," det. BB. as algens (nec Tachina algens Wiedemann, 1830, Auss. Zweifl. II, 285). Holotype, No. 19597 , U. S. Nat. Mus., female.

Differs from Larvavora as follows: Form a little less heavily widened. Third antennal joint longer. Front of female at vertex conspicuously greater than eye-width, that of male a little less than eye-width. Ocellar area and parafrontals of both sexes heavily polished, black, without bloom in any light. Cheeks also with polished black area. Frontal profile hardly longer than facial. Frontalia broader, shorter, equilateral. Cheeks of female about one-half eye-height, those of male less than that. Third antennal joint of male not so broadened, longer than wide. Only two strong lateral scutellars, no thick discal pile. First abdominal segment without median macro- 
chætæ in either sex; second with a median marginal pair normally; third with a loose marginal row. Second segment heavily arcuate on middle of anterior border, bulged forward. Anal segment not emarginate. Marginal row of macrochætæ of anal segment not sagittate. Hypopygium of male much narrower. Second to fourth front tarsal joints of female more heavily widened.

A female of E. piceifrons, collected by the writer at Melrose Highlands, Massachusetts, September 13, 1914, disclosed a uterus $70 \mathrm{~mm}$. in length which was estimated to contain over 13,000 eggs and maggots. The eggs occurred in as many as 24 rows abreast. TD437\%.

Jurinia nitida Wulp, 1882, Notes Leyd. Mus. IV, 82 , is a closely allied western form.

Fabriciodes, new genus.

Genotype, Fabriciodes montana Townsend, new species, for Echinomyia florum Coquillett, 1897, Rev. Tach. 144, pt., holotype labeled White Mts., N. H. (nec Tachina florum Walker, 1849, List IV, 722). Holotype, No. 19598, U. S. Nat. Mus.

Differs from Larvavoropsis as follows: Male. All macrochætæ weak, body long-hairy. Third antennal joint broadly rounded, nearly as long as second. First aristal joint may be somewhat elongate. Parafacials and parafrontals with hairs that are not bristly. Sternopleurals mixed with pile. Five lateral scutellars, with pile. Median marginal pair of bristles on first abdominal segment; discals and subdiscals on intermediate segments, but all weak; abdomen with long pile posteriorly and shorter pile anteriorly. Hypopygium heavier; claws not so elongate.

The genotype is distinguished by the wide black vitta of abdomen being spread over whole of anal segment, and the scutellum being wholly light testaceous.

Rhachogaster Townsend, 1915, Can. Ent. XLVII, 291.

Genotype, Rhachogaster kermodei T., 1. c.

The species may be distinguished from Echinomyodes piceifrons T. as follows: Form much less broadened; distinctly nar- 
rowed, especially in male. Male vertex little over one-fifth head-width, that of female about eye-width. Ocellar area and posterior half of female parafrontals polished black, without pollen in any light; the male showing bloom almost to vertex. Proboscis longer, palpi heavily thickened apically. Cheeks nearly three-fifths eye-height in female, one-half same in male. Anal segment with only marginal and submarginal macrochætæ. Male hypopygium large, with comb-toothed flanges. Brush of heavy spines on sides of venter of anal segment of male, less marked in female but present. Male ventral plates 2 and 3 spined as described and ventral profile deeply hollowed. Male tarsi much shortened.

The specimens referred to by Coquillett, 189\%, Rev. Tach. 144, White Mountains, New Hampshire (pt.), both sexes; Oswego, New York, two females, and (Camel's Hump) Vermont, male, are this species.

Eularvævora, new genus.

Genotype, Tachina algens Wiedemann, 1830, Auss. Zweifl. II, 285 .

Differs from Rhachogaster as follows: Second antennal joint of female longer and third somewhat smaller. Parafrontals pollinose in both sexes; palpi less thickened at tip; cheeks rather over one-half eye-height; both sexes with two to five median marginal macrochætæ on first segment and six to seven on second. Abdomen rather long-hairy in male, shortpilose in female. Macrochætæ somewhat weaker. Abdomen of female distinctly broadened, that of male a little less so. Male hypopygium much smaller and of distinct character, ventroanal spine-brushes not developed. Male tarsi not shortened. Second and third ventral plates of male with long bristles instead of spines, the ventral profile not deeply hollowed. Differs from Fabriciella by lack of ventroanal spinebrushes.

Wiedemann evidently had a female with dark or discolored antennæ.

The specimens referred to by Coquillett, 1897, Rev. Tach. 144, Franconia, New Hampshire, male, and White Mountains, 
New Hampshire (pt.), both sexes, are this species. The male abdomen is more or less reddish on sides, the palpi and first two antennal joints are yellowish to rufous. Otherwise fits Wiedemann's description. No other species known to me fits as well. It is quite probable that $T$. algens $\mathrm{Wd}$. was a composite species, including the female of the present form and the male of the preceding, for the author probably had several specimens. In such case the species must stand restricted as above.

\section{Family EXORISTID层}

Trisisyropa, new genus.

Genotype, Trisisyropa vesiculata Townsend, new species.

Differs from Winthemia as follows: Female. Much narrower in form, the entire length conspicuously over three times the greatest width. The whole head and appendages are so similar to those of Winthemia as to defy exact verbal differentiation, but the front is more prominent in profile, the frontalia are nearly or quite as wide as one parafrontal, and the bristles of head are in general stronger. Anal segment practically without hairs among the bristles both above and below. Abdomen narrowed, long-ovate. Hind tibiæ not ciliate, only very loosely-pectinate with longer bristles present. Small crossvein opposite point halfway between end of auxiliary and end of first vein or nearer to latter. Cubitus considerably greater than a right angle, the apical crossvein less bent in. No median marginal macrochætæ on first abdominal segment. Has a pair of large inflatable uterovaginal pouches in common with Winthemia.

Trisisyropa vesiculata, new species.

Length of body, $8.5 \mathrm{~mm}$.; greatest width, $2.5 \mathrm{~mm}$; length of wing, $6 \mathrm{~mm}$. One female, Lakehurst, Sebago Lake, Maine, September 6, 1914, on foliage ('Townsend).

Frontalia black, antennæ blackish with some rufous on inside of third joint, palpi pale rufous, face wholly silvery-white, parafrontals golden. Thorax shining black, with silvery pollen which is thinnest on disk, leaving five inconspicuous vittæ. 
Scutellum testaceous, except the black base, thinly silvery. Abdomen shining black, thickly silvery-white pollinose on bases of last three segments, the rest of surface showing thin bloom in oblique light, anal segment bright rufous on posterior half, a patch of obscure rufous on sides of second segment. Venter wholly blackish, except the pale testaceous hind borders of segments. Legs black. Wings clear. Tegulæ white.

Holotype, No. 19600, U. S. Nat. Mus. TD4355.

Neothelaira Townsend.

Journ. N. Y. Ent. Soc. XX, 109-110 (June, 1912).

Genotype, Masicera aurifrons Coquillett, 1897, Rev. Tach. 115 (Syn. Neothelaira dexina Townsend, 1912, 1. c., holotype, No. 19466, U. S. Nat. Mus., TD427).

Front of female slightly exceeding one-third head-width at vertex, widening rather evenly into face; that of male hardly one-third same, with parallel sides on nearly posterior half; face about one and three-fourths times vertex in female, that of male nearly twice vertex. Frontalia in middle a little narrower than one parafrontal at same point. Parafacials broad, averaging wider than length of second antennal joint. Front well produced in profile, facial profile equal to or slightly longer than frontal; epistoma normally weakly prominent, not cut off, slightly constricted, the vibrissæ inserted a little above the extreme oral margin. Vibrissal axis of head only a little shorter than antennal axis, due to the strong bulging of occiput below; the face very receding. Facialia practically bare, only a few short bristles next vibrissæ; facial depression not broad, rather long, shallow. Cheeks in both sexes nearly to fully one-half eye-height. Outer verticals but slightly developed, strong pair of proclinate ocellars; two proclinate and two reclinate fronto-orbitals in female, three or four reclinate in male; five pairs of frontals in female, seven or eight in male, which descend to point below root of arista. Second antennal joint moderately elongate; third narrow, about two and one-half to three times second; arista not longer than third antennal joint, well thickened on over basal half, tapered rapidly, sharply pointed, basal joints short. Proboscis about 
head-height, stout; palpi rather stout, a little shorter than third antennal joint, thickened distally. Sternopleurals, postsuturals, and postacrostichals all three in number. Scutellum with four laterals, the front and hind ones longest, latter reaching to base of third segment; a weak erect decussate apical pair, and an approximated weak discal pair, with some additional discals in male. Whole form narrowed, abdomen about same width as head and thorax. Venter of female is not carinate (stated by Coquillett to be carinate, 1. c.). Abdominal macrochætæ discal and marginal, the latter long, the discals short, all erect; median marginal pair on first segment; no marginals on anal segment of female, except short ones like the discals, but anal segment of male is well covered with strong ones. Hind tibiæ not ciliate or pectinate. Apical cell ending well before wing-tip, closed or narrowly open; cubitus angular, with faint wrinkle; apical crossvein only slightly bent in and subparallel with hind one, which is nearer to cubitus; strong costal spine. Third vein spined nearly halfway or almost to small crossvein, other veins bare. Last section of fifth vein is almost half as long as preceding section. Legs of moderate length; claws of female nearly or quite as long as last tarsal joint, those of male distinctly more elongate.

Neothelaira aurifrons Coquillett.

Length of body, $9 \mathrm{~mm}$. (females rather flexed); of wing, $6.5 \mathrm{~mm}$. One female, holotype of dexina, TD427, Lynn, Massachusetts, August 28, 1908 (F. B. Lowe); holotype of aurifrons, female, Mount Washington, New Hampshire (Slosson); allotype, male, White Mountains, New Hampshire (Morrison).

Entire parafacials, cheeks, occipito-orbits, vertex, and parafrontals deep rich gold in female, the whole facial plate and facialia gold to gray-golden; in male more obscurely golden, the parafrontals largely blackish; frontalia and arista dark brown; antennæ blackish, the first two joints and base of third rufous; palpi pale rufous. Occiput silverycinereous. Thorax, scutellum, and abdomen shining black, silvery pollinose; mesoscutum with four vittæ, the outer 
ones of the semicolon type, the inner ones sublinear and reaching well behind suture, a fifth vitta showing in middle behind suture. First abdominal segment black, the broad hind borders of second to fourth shining black and without pollen. The silvery of bases of last three segments is narrower in the male. Legs black, femora pollinose, tibiæ with a rufous-brown tinge. Wings clear. Tegulæ nearly white. The anal segment of female may be slightly or broadly tipped with rufous.

Masicera chatoneura Coquillett, 189\%, Rev. Tach. 115, from the White Mountains, New Hampshire, belongs to this genus.

Hylotomomyia, new genus.

Genotype, Admontia hylotome Coquillett, 1898, Can. Ent. XXX, 233.

Differs from allied genera with piercer as follows: Lateral edges of tergal sclerite of third segment in female meeting on median ventral line and set with row of closely-placed very short spines, forming a weak ventral carina when venter is not collapsed; a short piercer present in female. Parafacials with an area of fine hairs on lower portion. Facialia ciliate onefourth to one-third way up. Vibrissæ inserted above oral margin. Head subtriangular in profile, the lower border very short and rather rounded. Parafacial profile faintly convex. Antennæ shortened, not reaching vibrissæ in either sex; second joint elongate. Cheek grooves ascending broadly behind eyes. Strong discal bristles in male, weak ones in female. Abdomen rather thickly clothed with bristly hairs, especially in male. Costal spine present. Cubitus broadly rounded, the hind crossvein a little nearer to same than to small crossvein. Apical cell open to almost closed, ending a little before wing-tip. Allied to Spathimeigenia, from which it may be at once known by the lack of short spines on ventral edges of anal segment.

The holotype is a male, Woods Hole, Massachusetts.

Euzenillia Townsend.

Ann. Ent. Soc. Amer., IV, 148 (June, 1911).

Journ. N. Y. Ent. Soc., XX, 111-112 (June, 1912).

Genotype, Hypostena variabilis Coquillett, 1895, Journ. N. Y. Ent. Soc., III, 57 (Syn. Euzenillia aurea Townsend, 1911- 
12, 1. c., holotype, No. 19469 , U. S. Nat. Mus., TD350).

Differs from Tachinophyto as follows: Female. Vertex scarcely or well under one-third head-width. Head not so triangular in profile, the vibrissal axis longer. Front widening very gradually anteriorly, the face widening more rapidly. Facial depression wider, the parafacials narrower. Second antennal joint only slightly elongate; the third over three times as long as second, broader and stouter. Short median discals on intermediate abdominal segments, and a median marginal pair on first segment. Wings not so broad, longer; costal spine small ; apical cell open, ending distinctly before wing-tip; hind crossvein a little nearer to cubitus. No piercer to larvipositor. TD 4470 , topotype of variabilis, shows same maggots as TD350.

Male has second antennal joint very short; third being very long, about six times second. The claws are not elongate, the front is about same as that of female, and there are two proclinate fronto-orbitals. There are no median discals on intermediate abdominal segments. These characters are drawn from a specimen, Bureau Ent. No. $153^{\circ}$, reared by Koebele in Sonoma County, California, from Carpocapsa pomonella. It may be only a western subspecies of variabilis.

The arista is thickened on basal third in both sexes, the facialia are bare save for a few bristles next vibrissæ, and the legs are longer than in Tachinophyto.

NoTE.-The original description of Tachinophyto is of the male. Both sexes have two proclinate orbitals and short claws. The male front is but little narrower than that of the female. The facialia may be ciliate more than one-third way up, and the apical cell is often open. The female is provided with a piercer. These characters are drawn from two specimens which I identify as Tachinophyto floridensis T., being a male from southern Florida (Robertson, No. 12384), and a female from the District of Columbia, July.

\section{Family RHODOGYNIDÆ}

Neocyptera, new genus.

Genotype, Ocyptera dosiades Walker, 1849, List IV, 695. 


\section{$2 \mathrm{BHL}$ Biodiversity Heritage Library}

1916. "Elucidations of New England Muscoidea." Insecutor inscitiae menstruus 4, 17-32. https://doi.org/10.5962/bhl.part.8947.

View This Item Online: https://www.biodiversitylibrary.org/item/34104

DOI: https://doi.org/10.5962/bhl.part.8947

Permalink: https://www.biodiversitylibrary.org/partpdf/8947

\section{Holding Institution}

Smithsonian Libraries

\section{Sponsored by}

Smithsonian

\section{Copyright \& Reuse}

Copyright Status: NOT_IN_COPYRIGHT

This document was created from content at the Biodiversity Heritage Library, the world's largest open access digital library for biodiversity literature and archives. Visit BHL at https://www.biodiversitylibrary.org. 